PIOTR MICKIEWICZ

Uniwersytet Gdański

\title{
Kierunki przeobrażeń rosyjskiej polityki energetycznej w świetle zapisów Strategii bezpieczeństwa ekonomicznego Federacji Rosyjskiej do 2030 r. i amerykańskiej koncepcji eksportu gazu skroplonego
}

\author{
Directions of transformation of Russian energy policy \\ in the light of the provisions of the economic security strategy \\ of the Russian Federation until 2030 \\ and the American concept of export of liquefied gas
}

The article forecasts potential transformations of Russian energy policy after adopting the economic security strategy. It has been assumed that the goals of the energy policy will be to dominate supplies and create development processes in selected regions of the world. Their achievement requires technological transformation and production capabilities that would allow the creation of global gas prices and access to new markets. The necessary condition is cooperation with the most important importer (China) and the 'energy dependency' of new customers. This will change the nature of Russian energy policy and concepts of international influence

Keywords: energy policy, economic security strategy, Russia

Słowa kluczowe: polityka energetyczna, strategia bezpieczeństwa ekonomicznego, Rosja

Rosyjska polityka bezpieczeństwa obejmuje znacznie szerszy zakres zagadnień niż tylko zapewnienie bezpieczeństwa państwa. Mieszczą się w niej także przedsięwzięcia mające umożliwić władzom centralnym sprawowanie pełnej jurysdykcji nad podmiotami administracyjnymi Federacji Rosyjskiej oraz działania ukierunkowane na realizację interesów narodowych. Istotnym zadaniem rosyjskiej polityki bezpieczeństwa jest także wykorzystanie potencjału militarnego do wspierania procesów umożliwiających usankcjonowanie mocarstwowej pozycji oraz uzyskanie wpływu na kształt globalnych procesów 
polityczno-gospodarczych ${ }^{1}$. W działaniach tych kluczową rolę odgrywają sektor paliwowo-energetyczny oraz polityki sektorowe, których celem jest zapewnienie możliwości eksportu nośników energii. Traktowany jest on jako istotny element polityki bezpieczeństwa państwa, zapewniający Federacji Rosyjskiej stabilność finansową i umożliwiający kształtowanie regionalnego ładu międzynarodowego. Każda zmiana status quo na globalnym rynku nośników energii traktowana jest przez Rosję jako zagrożenie lub co najmniej wyzwanie dla jej bezpieczeństwa. Taki status nadano przede wszystkim amerykańskim koncepcjom wykorzystania tego rynku, będących w swej istocie instrumentem zapewniającym USA globalną dominację. Przez pierwszą dekadę XXI w. koncepcja ta sprowadzała się do uzyskania przez Stany Zjednoczone możliwości kontroli globalnych szlaków wymiany towarowej i eksploatacji środkowoazjatyckich złóż gazu ziemnego. W połowie drugiej dekady obecnego stulecia Amerykanie zdecydowali się na jej rozszerzenie o aktywne uczestnictwo w obrocie surowcami energetycznymi, głównie poprzez eksport gazu skroplonego. Poprzedzone długotrwałymi analizami (zwłaszcza konsekwencji ekonomicznych) zniesienie zakazu eksportu gazu ziemnego prowadzi do przeobrażenia zarówno rynku obrotu tym nośnikiem energii, jak i geopolitycznego układu sił. Decyzja ta uznana została przez Rosję za jedno z najistotniejszych zagrożeń dla jej bezpieczeństwa, gdyż wykreowała określone konsekwencje zarówno dla rosyjskiej gospodarki, jak i obowiązującej formuły oddziaływania międzynarodowego. Amerykański eksport nośników energii doprowadził do zmiany rosyjskiej polityki w sferach gospodarki i bezpieczeństwa oraz koncepcji oddziaływania międzynarodowego. Proces ten zapoczątkowany został w roku 2015, tuż po przedstawieniu przez Energy Information Administration opinii o zasadach, jakimi powinna się kierować polityka eksportu gazu$^{2}$. Za najistotniejsze wynikające $\mathrm{z}$ tej koncepcji zagrożenie rosyj-

1 Szerzej: P. Mickiewicz, Polityka bezpieczeństwa i doktryna obronna FR na przetomie XX i XXI wieku, [w:] Rosyjska myśl strategiczna i potencjat militarny w XXI wieku, red. P. Mickiewicz, Wydawnictwo Naukowe PWN, Warszawa 2018, s. 60-96.

2 W ogłoszonym 29.10.2014 r. stanowisku EIA rekomendowała uchylenie zakazu sprzedaży tego surowca za granicę, ale z zachowaniem limitów, na które decydujący wpływ powinny mieć warunki na rynku wewnętrznym. Według tych założeń eksport LNG miał spowodować w USA zwiększenie zużycia energii pierwotnej i emisji dwutlenku węgla do atmosfery o $0,1-0,6 \%$. Wzrost kosztów ponoszonych przez odbiorców indywidualnych szacowano natomiast na nie więcej niż $8 \%$, przy sumarycznym wzroście amerykańskiego PKB między $0,05 \%$ a $0,17 \%$. Effect of increased levels of liquefied natural gas exports on U.S. energy markets, U.S. Energy Information Administration, Washington, October 2014, s. 13-14, 25-27, dostępny w internecie [dostęp: 16.03.2018]: <https:// www.eia.gov/analysis/requests/fe/pdf/lng.pdf>. 
scy politycy uznali nie tyle skalę eksportu (nie więcej niż 15\% produkcji), ale zalecenie, by odbiorcami amerykańskiego gazu skroplonego były wyłącznie państwa uznane za strategicznych partnerów politycznych.

\section{Rosja wobec amerykańskiej koncepcji zniesienia zakazu eksportu surowców energetycznych}

Decyzja o zniesieniu zakazu eksportu gazu przez USA została uznana przez Rosję za zagrożenie w wymiarze politycznym i ekonomicznym. Początkowo bagatelizowano znaczenie potencjalnego spadku cen surowca, ponieważ gdyby był radykalny, oddziaływałby negatywnie także na amerykańską gospodarkę $^{3}$. Z rosyjskiego punktu widzenia zasadniczymi problemami są realne ograniczenie możliwości zwiększenia skali i poszerzenia zakresu terytorialnego eksportu oraz - dostrzeżone w 2017 r. - ekonomiczne skutki spadku dochodów państwa. Za istotne konsekwencje polityczne tej decyzji uznano w Moskwie przyjęcie przez waszyngtońską administrację zasady, że potencjalnymi odbiorcami amerykańskiego gazu LNG będą głównie państwa sojusznicze poddane rosyjskiemu oddziaływaniu polityczno-ekonomicznemu. Ogranicza to Rosji możliwości budowy strefy wpływów polityczno-gospodarczych oraz usankcjonowania pozycji współkreatora ładu międzynarodowego. Uderza także w realizowaną od 2000 r. politykę sukcesywnego wypychania Stanów Zjednoczonych z regionów, gdzie ulokowane są żywotne interesy Federacji Rosyjskiej.

Proces tworzenia rosyjskiej koncepcji przeciwdziałania konsekwencjom amerykańskiej polityki eksportu nośników energii prowadzony jest w dwóch skorelowanych formułach. Pierwszą stanowią przedsięwzięcia polityczno-militarne, mające na celu ograniczenie możliwości amerykańskiego oddziaływania na rosyjski system eksportu. Koncentrują się one na ograniczaniu możliwości eksportowych innych dostawców oraz uzyskaniu pełnej kontroli nad obszarami potencjalnego prowadzenia wymiany handlowej. W ramach realizacji tej polityki przeprowadzone zostały prace planistyczne dotyczące budowy Nord Stream 2 oraz zwiększenia możliwości handlu z państwami regionu kaspijskiego. Zasadniczą rolę odgrywały jednak przedsięwzięcia polityczno-militarne umożliwiające uzyskanie kontroli nad Morzem Czarnym i wschodnią częścią Ukrainy, kontrolę wybranych akwenów atlantyckiego kierunku narodowej polityki morskiej (Bałtyku, Morza Północnego i Morza

3 Tamże. 
Śródziemnego) oraz sankcjonujące rosyjską pozycję na akwenie Oceanu Arktycznego ${ }^{4}$. Realizacja tej polityki sprowadzona została do kreowania incydentów morskich oraz prób polityczno-militarnej izolacji najważniejszych dla USA państw tych regionów (Wielkiej Brytanii i Polski) lub poszerzenia wzajemnej kooperacji gospodarczo-politycznej (z Turcją i Włochami) ${ }^{5}$. Druga formuła to kompleksowe kilkuetapowe przedsięwzięcia o charakterze gospodarczym. W pierwszym okresie ich realizacji, obejmującym lata 2015-2016, Rosja skoncentrowała się na ocenie potencjalnych konsekwencji amerykańskiej polityki eksportowej i opracowaniu planu reagowania. Przyjęta koncepcja niwelowania negatywnych zjawisk w rosyjskiej gospodarce sprowadzona została do modyfikacji pięciu najistotniejszych polityk sektorowych ${ }^{6}$. Zawarta w nich wizja rosyjskiego oddziaływania zakładała ograniczoną zmianę polityki eksportu surowców, która w niewielkim stopniu wpływała na sposób kreowania regionalnego ładu międzynarodowego i formę rywalizacji z USA. Przeprowadzone w 2015 r. pierwsze rosyjskie analizy ekonomiczne i oceny politycznych skutków potencjalnego zniesienia zakazu eksportu gazu przez Stany Zjednoczone przewidywały, że wymuszą one jedynie rewizję dotychczasowej polityki energetycznej. Zakładano, że zasadniczymi konsekwencjami będą globalny spadek zapotrzebowania na nieprzetworzone nośniki energii o około $0,3 \%$ rocznie oraz niewielka obniżka cen surowca. $\mathrm{W}$ tej sytuacji za zagrożenie istotniejsze niż skala potencjalnego amerykańskiego eksportu uznana została europejska polityka suwerenności energetycznej. Koncentrując się na przeciwdziałaniu zapisom trzeciego pakietu energetycznego, Rosjanie zignorowali polityczne znaczenie skierowania amerykańskiego eksportu LNG do Polski oraz - potencjalnie - Litwy, Łotwy i Estonii. Doprowadziło ono do uznania przez USA Morza Bałtyckiego za region strategiczny, co radykalnie zmienia rosyjską pozycję polityczną w regionie i jej

$4 \quad$ W rosyjskiej doktrynie morskiej globalne akweny podzielone zostały na pięć narodowych kierunków polityki morskiej: arktyczny, atlantycki, Pacyfiku, kaspijski i Oceanu Indyjskiego. Każdy z nich obejmuje kilka wyszczególnionych akwenów morskich, wobec których zdefiniowano cele strategiczne i zasadnicze sposoby ich osiągania. Kierunek atlantycki to akweny Atlantyku Północnego: Morze Czarne, Morze Azowskie, Morze Śródziemne, Morze Północne oraz Bałtyk. Kierunek arktyczny to akweny Oceanu Arktycznego oraz północne akweny Pacyfiku (do Morza Ochockiego).

5 P. Mickiewicz, Baltycka ,zimna wojna”. Możliwe reakcje NATO i UE na rosyjska aktywność militarna na akwenie bałtyckim, „Krakowskie Studia Międzynarodowe” 2015, nr 2 (12), s. 57-70; tenże, Ewolucja rosyjskiej polityki bezpieczeństwa i doktryny obronnej w drugiej dekadzie XXI wieku, [w:] Rosyjska myśl strategiczna..., s. 136-139.

6 Od 2000 r. rosyjska polityka kształtowana jest w oparciu o założenia i cele strategiczne nakreślone w pięciu strategiach sektorowych. Ten swoisty kwintet strategiczny stanowią strategie energetyczna, transportowa i bezpieczeństwa, doktryna morska oraz tzw. koncepcja polityki zagranicznej. Szerzej: Rosyjska myśl strategiczna..., s. 63-64. 
politykę transportową ${ }^{7}$. Moskwa była też przekonana, że zapotrzebowanie na dostawy gazu ziemnego do Europy spowoduje zmianę stosunku państw europejskich do sytuacji na Ukrainie. Istotą prowadzonej w tym okresie polityki było kreowanie w nich przekonania, że Rosja zrekompensuje sobie straty wynikające z ograniczenia eksportu do krajów UE poprzez uzyskanie dostępu do nowych rynków zbytu, zwłaszcza w Azji kontynentalnej i Ameryce Południowej ${ }^{8}$. Przyjęte założenia określiły sposób uzyskiwania możliwości eksportu gazu skroplonego i przetworzonych nośników energii drogą morską. Rzeczywistym celem opracowanej w latach 2015-2016 koncepcji było jednak raczej stworzenie narracji ograniczającej UE możliwość realizacji projektu trzeciego pakietu energetycznego ${ }^{9}$. W praktyce prowadzone w tym okresie działania Rosji skoncentrowane zostały na próbie uzyskania kontroli nad arktyczno-atlantyckim, arktyczno-pacyficznym i śródziemnomorskim szlakiem żeglugowym oraz polityce ograniczania eksportu do Europy surowców energetycznych z Azji Centralnej. Osiągnięcie tego celu możliwe było tylko poprzez zdominowanie regionu kaspijsko-czarnomorskiego oraz równolegle prowadzoną politykę rozbudowy potencjału floty wojennej i uzyskiwanie zdolności do działania na wybranych akwenach globu. Determinowało to kroki podejmowane zarówno wobec państw eksportujących nośniki energii z obszaru kaspijskiego, jak i Ukrainy. Polityka kaspijska Federacji Rosyjskiej to głównie projekty mające zwiększyć możliwości przesyłu środkowoazjatyckich surowców energetycznych przez istniejące już postradzieckie systemy, a także działania zmierzające do zawarcia porozumienia o statusie prawnym Morza Kaspijskiego ${ }^{10}$. Celem działań podejmowanych wobec Ukrainy było

7 P. Mickiewicz, Rosyjsko-chińska aktywność morska i koncepcje obecności na akwenie baltyckim. Pomiędzy rywalizacją a wspótpraca, „Krakowskie Studia Międzynarodowe” 2018, nr 3 (15), s. 91-94.

8 Ènergetičeskaâ strategiâ Rossii na period do 2035 goda [projekt], s. 4-12, dostępny w internecie [dostęp: 10.09.2017]: <https://minenergo.gov.ru/system/download-pdf/1920/69055>.

9 K. Kosowska, P. Kosowski, Perspektywy rozwoju LNG w Rosji, ,Zeszyty Naukowe Instytutu Gospodarki Surowcami Mineralnymi i Energią PAN”2016, nr 95, s. 69-72.

10 Podpisana w sierpniu 2018 r. konwencja o statusie Morza Kaspijskiego pozornie ogranicza rosyjską hegemonię w regionie, gdyż umożliwia powstanie podmorskiego gazociągu z Turkmenistanu do Azerbejdżanu, który daje możliwość eksportu surowca do Europy poprzez terytorium Gruzji lub Turcji. Rosyjska akceptacja dla tego rozwiązania jest wynikiem kompromisu, który przewiduje, że na Morzu Kaspijskim działalność wojskową prowadzić będą mogły wyłącznie państwa sygnatariusze porozumienia. Rozwiązanie to ogranicza możliwości amerykańskiej obecności wojskowej w Azji Centralnej, a potencjał bojowy rosyjskiej Flotylli Kaspijskiej pozwala na uzyskanie pełnego panowania na tym akwenie. Aneksja Krymu dała Rosji możliwość kontrolowania Morza Czarnego, co przy charakterze współpracy z Turcją niweluje część negatywnych dla Moskwy konsekwencji ewentualnego eksportu kaspijskiego gazu do Europy. 
nie tylko ograniczenie jej suwerenności, ale także zniwelowanie możliwości pełnienia przez nią roli kraju partnerskiego USA. Dzięki takim relacjom Amerykanie mogliby usankcjonować swoją obecność w regionie kaspijsko-czarnomorskim i stworzyć alternatywny wobec rosyjskiego system transportu surowców energetycznych, wykorzystując gruzińską i ukraińską infrastrukturę przesyłową oraz możliwości przeładunkowe portów obu państw. Agresja na wschodnią Ukrainę, a zwłaszcza aneksja Krymu, umożliwiła także zdominowanie Morza Azowskiego, północnej i wschodniej części Morza Czarnego oraz ponowne określenie czarnomorskiej strefy wyłączności ekonomicznej (EEZ) obu państw. Rozwiązanie to stworzyło korzystną sytuacje strategiczną, która pozwala Rosji na powrót do realizacji koncepcji budowy gazociągu South Stream ${ }^{11}$. Polityczno-ekonomiczna współpraca z Turcją stwarza z kolei ograniczenia dla realizacji alternatywnych wobec rosyjskich projektów podmorskich systemów przesyłu nośników energii, zwłaszcza Euroazjatyckiego Korytarza Transportu Ropy Naftowej.

Powyższe działania zostały skorelowane z przedsięwzięciami prowadzonymi w ramach zmodyfikowanych na przełomie 2015 i 2016 r. rosyjskich strategii transportu i bezpieczeństwa oraz doktryny morskiej. Strategicznym celem polityk morskiej i bezpieczeństwa pozostały kwestie zniwelowania dominacji USA w zakresie kontroli szlaków międzykontynentalnej wymiany handlowej oraz polityczno-ekonomicznych konsekwencji amerykańskiej decyzji o formule eksportu LNG. Mniejsze znaczenie przypisano działaniom mającym na celu utrzymanie kontroli nad strategicznymi obszarami wydobycia surowców energetycznych w Azji i istniejącymi systemami przesyłowymi. O takim podejściu rosyjskich strategów i polityków świadczą zarówno merytoryczne treści nowelizacji, jak i kolejność wdrażania zaktualizowanych dokumentów strategicznych. Jako pierwszą znowelizowano doktrynę morską (26 listopada 2015 r.), dostosowując jej zapisy do zmienionej po zajęciu Krymu sytuacji geopolitycznej oraz koncepcji transportu LNG z terminali na Półwyspie Jamalskim. Celem polityki morskiej stało się zwiększenie rosyjskich możliwości transportowych

11 Przesuniecie rosyjskiej strefy wyłączności ekonomicznej powoduje, że wytyczona trasa gazociągu przebiega przez EEZ Rosji i Bułgarii. Opanowanie półwyspu pozwoliło ponadto na kontrolę lądowych i morskich szlaków transportowych w zlewisku Morza Czarnego, Morza Azowskiego i Morza Kaspijskiego oraz zwiększenie potencjału oddziaływania na akwenie śródziemnomorskim. Umożliwiło także zniwelowanie możliwości wykorzystania portów gruzińskich i ukraińskich jako istotnych punktów przeładunku surowców energetycznych przesyłanych z Azji Centralnej do Europy. O. Voytyuk, Sektor naftowy Ukrainy. Historia i przyszłość, „Polityka Energetyczna” 2015, t. 18, z. 2, s. 139-140; P. Mickiewicz, Obszar czarnomorski i Morze Śródziemne w polityce Rosji, „Rocznik Bezpieczeństwa Międzynarodowego” 2016, vol. 10, nr 1, s. 75-77, 79. 
poprzez inwestycje w systemy i środki przewozowo-przeładunkowe umożliwiające transport morski na Pacyfiku, Oceanie Arktycznym, Morzu Śródziemnym i Bałtyku ${ }^{12}$. Inwestycje te skorelowane zostały z koncepcją przeobrażeń sektora paliwowo-energetycznego i założeniami polityki eksportu nośników energii. Zawarto je w dokumencie pt. Prognoza rozwoju naukowego i technologicznego rosyjskiego przemystu paliwowo-energetycznego na okres do 2035 r. Dokonano tam szczegółowej analizy niezbędnych inwestycji w rozwój infrastruktury portowej, w tym terminali LNG i paliwowych ${ }^{13}$. W drugiej kolejności dokonano nowelizacji zapisów strategii bezpieczeństwa narodowego (31 grudnia 2015 r.) i koncepcji polityki zagranicznej (30 listopada 2015 r.). Obydwa dokumenty zakładały prowadzenie komplementarnych działań umożliwiających osiąganie rosyjskich interesów strategicznych, a zwłaszcza przedsięwzięć pozwalających na kształtowanie - także przy użyciu narzędzi militarnych ${ }^{14}$ - regionalnego ładu międzynarodowego, a także zapewniających rozwój i zwiększenie konkurencyjności rosyjskiej gospodarki ${ }^{15}$. Pierwsze realistyczne oceny konsekwencji, jakie amerykańska decyzja o zniesieniu zakazu sprzedaży surowców za granicę przynosi rosyjskiej polityce eksportu nośników energii, zawarte zostały dopiero w strategii rozwoju transportu śródlądowego oraz sprawozdaniu $\mathrm{z}$ realizacji strategii transportowej ${ }^{16}$. W dokumentach tych sformułowano także

12 Morskâ̂ doktrina Rossijskoj Federacii, s. 2-3, 16-17, 49-72, dostępna w internecie [dostęp: 21.04.2017]: <http://static.kremlin.ru/media/events/files/ru/uAFi5nvux2twaqjftS5yrIZUVTJan77L.pdf $>$.

13 Prognoz naučno-tehnologičeskogo razvitiâ otraslej toplivno-ènergetičeskogo kompleksa Rossii na period do 2035 goda, Ministerstvo Ėnergetiki Rossijskoj Federacii, Moskva 2016, s. 4-92, dostępny w internecie: <https://minenergo.gov.ru/view-pdf/6365/66647>.

14 Poprzez prowadzenie działań kwalifikowanych jako smart power, w tym prezentację siły, kreowanie incydentów, stałą obecność wojskową w regionie, wykorzystanie lokalnych zjawisk politycznych do prowadzenia operacji stabilizujących sytuację w regionie.

15 Ukaz Prezidenta Rossijskoj Federacii ot 31 dekabrâ 2015 goda N 683 „O Strategii nacional'noj bezopasnosti Rossijskoj Federacii”, „Rossijskaâ gazeta” [online], 31.10.2015 [dostęp: 21.04.2017], p. 3, 7, dostępny w internecie: $<$ https://rg.ru/2015/12/31/ nac-bezopasnost-site-dok.html>; Koncepcja polityki zagranicznej Federacji Rosyjskiej (zatwierdzona przez Prezydenta Federacji Rosyjskiej Vladimira Putina 30 listopada 2016 r.), „Ambasada Rosji w Polsce” [online, dostęp: 21.04.2017], p. 4, 42, 46, 48.e, 49, 51-53, 67, dostępna w internecie: <http://poland.mid.ru/web/polska_pl/koncepcjapolityki-zagranicznej-federacji-rosyjskiej/-/asset_publisher/x9WG6FhjehkG/content/ koncepcja-polityki-zagranicznej-federacji-rosyjskiej-zatwierdzona-przez-prezydentafederacji-rosyjskiej-vladimira-putina-30-listopada-2016-r-?inheritRedirect=false\&redirect $=$ http $\% 3 \mathrm{~A} \% 2 \mathrm{~F} \% 2 \mathrm{Fpoland} . \mathrm{mid} . \mathrm{ru} \% 2 \mathrm{Fweb} \% 2 \mathrm{Fpolska}$. pl\%2Fkoncepcja-politykizagranicznej-federacji-rosyjskiej\%3Fp_p_id\%3D101_INSTANCE_x9WG6FhjehkG\%26p_p_lifecycle $\%$ 3D0\%26p_p_state $\% 3 \bar{D}$ Dnormal $\% 26 \mathrm{p} \_\mathrm{p} \_$mode $\% \overline{3} \mathrm{Dview} \% 26 \mathrm{p} \_$_ col_id\%3Dcolumn-2\%26p_p_col_count $\% 3 \mathrm{D} 1>$.

16 Strategiâ razvitiâ vnutrennego vodnogo transporta Rossijskoj Federacii na period do 2030 goda, „Pravitel'stvo Rossii” [online, dostęp: 21.04.2017], dostępna w internecie: <http:// 
propozycje przeciwdziałania negatywnym konsekwencjom amerykańskiej koncepcji eksportu LNG. Za niezbędne uznano włączenie do 2030 r. rosyjskich systemów przewozowych i przesyłowych do globalnego systemu transportowego, co miało umożliwić ograniczenie ekspansji USA. Ponadto określone zostały geograficzne obszary rosyjskiej aktywności gospodarczej, która miała się koncentrować na terytoriach państw Wspólnej Przestrzeni Gospodarczej WNP, APEC, Szanghajskiej Organizacji Współpracy, Organizacji Współpracy Gospodarczej Morza Czarnego oraz Unii Europejskiej. Regiony te stanowić mają centralny obszar rosyjskiej wymiany handlowej, w tym eksportu surowców energetycznych i przetworzonych nośników energii.

Ostatnim etapem procesu modyfikacji rosyjskiego kwintetu strategicznego miała być nowelizacja strategii energetycznej. Na wstępie zakładano, że zasadniczym celem politycznym będzie realne, a nie tylko deklarowane uzyskanie możliwości eksportu LNG i wyrobów olejowych. W odróżnieniu od pozostałych strategii sektorowych okres obowiązywania tego dokumentu został wydłużony o pięć lat, miał on bowiem pełnić rolę głównej strategii sektorowej. Założono, że okres ten będzie etapem modyfikacji i wypracowania założeń na następną pięciolatkę. Podstawę do projektowania miały stanowić oceny efektów realizacji jej zapisów oraz celów przyjętych w pozostałych strategiach gospodarczych. Wobec decyzji Stanów Zjednoczonych o sprzedaży gazu do państw sojuszniczych założenia te okazały się jednak błędne. Pogłębiona ocena politycznych i gospodarczych konsekwencji amerykańskiej polityki eksportowej doprowadziła do wstrzymania prac koncepcyjnych nad nowelizacją tego dokumentu $\mathrm{w}$ drugiej połowie $2016 \mathrm{r} \cdot{ }^{17}$ Poziom zagrożenia wypchnięcia Rosji z części rynku obrotu gazem postawił Moskwę przed koniecznością przeobrażenia nie tylko koncepcji eksportu czy samej polityki energetycznej państwa, ale także polityki gospodarczo-społecznej. Jej założenia zostały zaprezentowane w nowym dokumencie strategicznym - ogłoszonej 13 maja 2017 r. Strategii bezpieczeństwa ekonomicznego Federacji Rosyjskiej do $2030 r^{18}$

static.government.ru/media/files/YxvWxYkzMqwAsfBmAX6anAVViKnFgYwA.pdf>; Doklad o realizacii transportnoj strategii Rossijskoj Federacii na period do 2030 goda. Otčetnyj period: 2015 god, Ministerstvo transporta Rossijskoj Federacii, Moskva 2016, s. 8, dostępny w internecie [dostęp: 21.04.2017]: <https://www.mintrans.ru/file/401707>.

17 Ėnergetičeskâa strategiâ... Formalnie projekt jest na etapie uzgodnień międzyresortowych (od września 2016 r.).

18 Ukaz Prezidenta Rossijskoj Federacii „O Strategii èkonomičeskoj bezopasnosti Rossijskoj Federacii na period do 2030 goda”, ,Èlektronnyj fond pravovoj i normativno-tehničeskoj dokumentacii” [online], 15.05.2017 [dostęp: 12.09.2017], dostępny w internecie: $<$ http://docs.cntd.ru/document/420398070>. 


\section{Przeobrażenia rosyjskiej polityki energetycznej w dobie wdrażania zapisów strategii bezpieczeństwa ekonomicznego}

Rosyjska strategia bezpieczeństwa ekonomicznego skonstruowana została w formie przypisywanej średniookresowym strategiom prorozwojowym. Kontekst powstania powoduje jednak, że należy ją uznać za dokument o dużo większym znaczeniu politycznym. Jest główną strategią kreującą politykę Federacji Rosyjskiej ukierunkowaną na likwidację zasadniczego zagrożenia bezpieczeństwa państwa. Po pogłębionych analizach uznano za nie właśnie amerykańską koncepcję eksportu nośników energii do strategicznych sojuszników, co wraz z kontrolowaniem przez USA globalnych szlaków transportowych znacząco ogranicza zarówno możliwości eksportowe Rosji, jak i jej zdolność do kreowania ładu międzynarodowego. Szczegółowe plany polityki prorozwojowej zawarte w strategii zakładają zwiększenie poziomu bezpieczeństwa ekonomicznego państwa, ale stanowią też wskazania dla koncepcji oddziaływania międzynarodowego. Określają tym samym cele przedsięwzięć prowadzonych w oparciu o strategie bezpieczeństwa i transportu oraz doktrynę morską i koncepcję polityki zagranicznej. Założono, że bezpieczeństwo ekonomiczne Rosji determinowane jest przez trzy czynniki: globalne przeobrażenia społeczno-gospodarcze, wewnętrzne procesy kreujące sytuację gospodarczą państwa oraz uwarunkowania społeczne. Specyfika ich oddziaływania powoduje, że państwo rosyjskie powinno prowadzić „kompleksowe przedsięwzięcia polityczne, instytucjonalne, społeczno-gospodarcze, prawne, informacyjne, dyplomatyczne, wojskowe oraz specjalne, których celem jest ograniczenie zakresu oddziaływania ekonomicznych zagrożeń bezpieczeństwa państwa"19. Za najistotniejsze zagrożenia dla stabilności ekonomicznej państwa uznano energochłonność rosyjskiej gospodarki oraz potencjalne zmniejszenie możliwości eksportowych (ograniczenie importu przez tradycyjnych odbiorców). Mniejsze znaczenie przypisano skutkom takich zjawisk, jak starzenie się systemów przesyłowych i coraz większe ograniczenia możliwości wydobycia paliw kopalnianych. Osobnej analizie poddane zostały konsekwencje społeczne istniejących ograniczeń rozwojowych, co spowodowało, że istotne znaczenie w działaniach na rzecz bezpieczeństwa ekonomicznego przypisano procesom rozwojowym o charakterze społeczno-gospodarczym. Takie uszeregowanie zagrożeń zdeterminowało średniookresowe cele dla rosyjskiej gospodarki i jej sektora paliwowo-energetycznego.

19 Tamże, p. 32-33. 
W przypadku polityki społeczno-gospodarczej zaliczono do nich zmniejszenie poziomu energochłonności, podjęcie inwestycji rozwojowych oraz wdrożenie niezbędnych procesów modernizacyjnych w wybranych sektorach gospodar$\mathrm{ki}^{20}$. Procesy inwestycyjne i modernizacyjne w sektorze paliwowo-energetycznym mają natomiast doprowadzić do zasadniczej zmiany struktury wytwarzania nośników energii. Założono, że po ich zakończeniu możliwe będzie zwiększenie produkcji przerobów olejowych, paliwa gazowego i lekkiego oleju opałowego o około $45-50 \%$ w przypadku paliw silnikowych i $30 \%$ w przypadku gazu skroplonego.

Prowadzona modernizacja poszczególnych segmentów przemysłu paliwowo-energetycznego ma także umożliwić pozyskanie nowych rynków zbytu nośników energii. Ekspansja gospodarcza Rosji skoordynowana jest z oddziaływaniem międzynarodowym, co ma na celu zarówno tworzenie więzów polityczno-gospodarczych z potencjalnymi odbiorcami, jak i aktywną ochronę interesów narodowych w wymiarze globalnym. Istotną rolę pełnią tu sektory transportu i gospodarki morskiej oraz komplementarne przedsięwzięcia prowadzone w ramach polityki zagranicznej i bezpieczeństwa, mające zapewnić dalsze wiązanie gospodarcze wybranych regionów ${ }^{21}$. Zasadnicze działania podejmowane $\mathrm{w}$ ramach polityk transportowej i morskiej to budowa ponadregionalnych systemów transportowych i przesyłowych oraz tworzenie atrakcyjnej oferty dostaw nośników energii i współpracy gospodarczej. Mają one zapewnić prowadzenie swobodnej wymiany handlowej (także drogą morską) oraz umożliwić państwu rosyjskiemu współkreowanie procesów polityczno-gospodarczych. Koncentrują się na tworzeniu powiązań „w ramach WNP, Unii Euroazjatyckiej, BRICS-u i Szanghajskiej Organizacji Współpracy oraz innych form integracji regionalnej i ponadregionalnej" w celu poszerzenia dotychczasowych form kooperacji gospodarczej, w tym prowadzenia wspólnych inwestycji w krajach partnerskich, oraz zwiększenia możliwości eksportu towarów nieolejowych ${ }^{22}$. Działania prowadzone w ramach polityki zagranicznej i bezpieczeństwa zmierzają natomiast do usankcjonowania rosyjskich uprawnień do prowadzenia nieskrępowanej aktywności gospodarczej w wybranych rejonach globu. Istotną rolę $\mathrm{w}$ tych działaniach przypisano rosyjskim siłom

20 Tamże, p. 14-15.

21 Koncepciâ vnešnej politiki Rossijskoj Federacii (utverždena Prezidentom Rossijskoj Federacii V.V. Putinym 30 noâbrâ 2016 g.), „Ministerstvo inostrannyh del Rossijskoj Federacii” [online, dostęp: 12.10.2017], p. 2, dostępny w internecie: $<$ http://www.mid.ru/ foreign_policy/news/-/asset_publisher/cKNonkJE02Bw/content/id/2542248>. 
zbrojnym, które mają zapewniać ochronę interesów państwa. Zasadniczą formułą ich wykorzystania jest dyslokacja w regionach wydobycia i transportu nośników energii, a pierwszoplanowym zadaniem - zapewnienie możliwości eksploatacji paliw kopalnianych w obszarach spornych oraz kontrola najistotniejszych szlaków żeglugowych. Mają także ograniczyć możliwość kontrolowania tych tras przez innych graczy międzynarodowych oraz stacjonowania ich sił zbrojnych w obszarach aktywności polityczno-ekonomicznej państwa rosyjskiego, zwłaszcza w Arktyce (wraz z Północną Drogą Morską), regionie kaspijsko-czarnomorskim oraz na Bałtyku. Militaryzacja tych regionów ma na celu ograniczenie możliwości polityczno-militarnego oddziaływania Stanów Zjednoczonych oraz zastosowania blokady morskiej jako środka oddziaływania na Rosję.

\section{Bezpieczeństwo ekonomiczne a ksztalt strategii energetycznej Federacji Rosyjskiej}

Zapisy strategii bezpieczeństwa ekonomicznego oraz innych dokumentów i ekspertyz pozwalają na zaprezentowanie długofalowych celów rosyjskiej polityki energetycznej i sposobów ich osiągania. Oceniając pierwszy rok wdrażania jej założeń, można uznać, że podjęto się realizacji punktowych projektów modernizacyjnych, skoncentrowanych na wybranych elementach infrastruktury wydobywczej i energetycznej ${ }^{23}$. Prowadzone od 2017 r. przedsięwzięcia to głównie projekty mające na celu unowocześnienie i rozbudowę systemów przesyłowych oraz istniejącej infrastruktury przerobu surowców ${ }^{24}$, a także działania zwiększające ekonomizację energetyczną odbiorców ${ }^{25}$. Cele te skorelowano z gamą regionalnych inicjatyw prospołecznych i prorozwojowych oraz zmodyfikowaną koncepcją eksportu surowców energetycznych. Zakres prowadzonych działań pozwolił jednak jedynie na uruchomienie

23 Ich zakres ograniczają głównie sankcje związane z agresją na Ukrainę, które utrudniają import niezbędnych urządzeń z krajów UE. Dodatkowym problemem jest dla Rosji fiasko planów uzyskiwania samowystarczalności w zakresie produkcji turbin dla elektrowni gazowych, których budowa miała być jednym z zasadniczych przedsięwzięć prorozwojowych.

24 Za zasadnicze zadanie o charakterze modernizacyjnym uznano transformację technologiczną sektora paliwowo-energetycznego w celu zwiększenia efektywności i obniżenia kosztochłonności wydobycia surowca oraz jego przesyłu systemami transportowymi.

25 Zadanie to zostało uwzględnione w kontekście potencjalnej rywalizacji na rynku obrotu surowcami w projekcie strategii energetycznej do 2035 r. Zob. Ėnergetičeskaâ strategiâ..., p. 4.7, 4.8 . 
lokalnych procesów rozwojowych o ograniczonym znaczeniu społecznym. Nie osiągnięto także celów mających zapewnić stabilność ekonomiczną państwa, zwłaszcza obniżenia energochłonności rosyjskiej gospodarki. Należy więc uznać, że celem długofalowym wciąż będzie uzyskanie przez rosyjski przemysł paliwowo-energetyczny zdolności do zmiany struktury produkcji oraz pozyskania nowych rynków zbytu. Podstawowym środkiem do ich opanowania ma być nie cena, ale rodzaj oferowanych produktów, głównie oleju napędowego i innych wyrobów olejowych oraz LNG. Przemysł paliwowo-energetyczny w dalszym ciągu ma być kreatorem działań prorozwojowych w sferze społecznej. Za priorytetowe inwestycje w system przesyłowy wciąż uznawane będą te projekty, które umożliwią wkomponowanie rosyjskich celów strategicznych w kształt polityk energetycznych najistotniejszych importerów. Decyzja, że nowymi priorytetowymi rynkami zbytu mają być kraje Azji i Pacyfiku, a podstawowym towarem eksportowym - gaz skroplony, określiła zakres przedsięwzięć w wymiarach średnio- i krótkookresowym. Ze względów politycznych oraz w celu uzyskania funduszy na realizację przyjętych projektów rozwojowych najważniejszymi inwestycyjnymi pozostaną systemy przesyłowe Nord Stream 2, Siła Syberii 2 oraz Vankor-Puree (i ewentualnie South Stream ${ }^{26}$ ). Za możliwe rozwiązanie należy też uznać podjęcie inwestycji umożliwiających eksploatację zasobów arktycznego szelfu kontynentalnego, ale i te działania będą miały o wiele większe znaczenie polityczne niż gospodarcze.

Istotnym długofalowym celem rosyjskiej polityki energetycznej będzie także niwelowanie skali eksportu nowych producentów oraz rosnącego znaczenia węglowodorów ze złóż nietradycyjnych i odnawialnych źródeł energii. Podejmowane będą także próby uzyskania wpływu na mechanizmy ustalania cen i regulacji światowych rynków energetycznych ${ }^{27}$. Mogą być też prowadzone działania ukierunkowane na włączenie rosyjskich przedsiębiorstw w inwestycje energetyczne w wybranych państwach (na wzór aktywności w Turcji i Iranie przy instalacjach jądrowych) i szersze wykorzystywanie doświadczeń niemieckich (jak budowa gazowych bloków energetycznych). Realizowane będą także przedsięwzięcia mające zapewnić zrównoważony rozwój społeczno-ekonomiczny: poszerzanie gamy wykorzystywanych źródeł energii

26 Gazociąg South Stream może być realizowany wyłącznie z powodów politycznych, m.in. w celu wykorzystania faktu zaangażowania się w jego budowę grupy państw z południowej Europy. Zajęcie Krymu pozwoliło natomiast wykreować sytuację, w której Rosja może dowodzić, że będzie on przebiegał w jej wyłącznej strefie ekonomicznej (EEZ).

27 Ėnergetičeskaâ strategiâ..., p. 5. 
(zwłaszcza w regionach, gdzie występują jej deficyty) oraz zapewnienie ciągłości dostaw i stabilności cen energii na poziomie odpowiadającym możliwościom nabywczym społeczeństwa ${ }^{28}$.

Opierając się na powyższych założeniach oraz zapisach dokumentów wykonawczych ${ }^{29}$, można wskazać następujące cele budowane w układzie horyzontalnym, zakładającym 5-letni (cele krótkookresowe) oraz 12-15-letni (średniookresowe) okres realizacji. Zasadniczym celem średniookresowym (do 2030 r.) rosyjskiej polityki energetycznej powinno być sukcesywne zwiększanie elastyczności eksportowej, osiągane poprzez uzyskiwanie dostępu do kolejnych rynków oraz rozbudowę sieci przesyłowych i terminali paliwowych, w tym umożliwiających transport LNG. Cel ten i sposób jego osiągnięcia określają zarówno zakres, jak i czas realizacji projektów modernizacyjnych i inwestycyjnych. Należy uznać, że w pierwszym okresie (do roku 2022) działania modernizacyjne koncentrować się będą na stopniowym zwiększaniu efektywności produkcyjnej, a inwestycje pozostaną na etapie przygotowań do realizacji konkretnych projektów innowacyjnych. Będą one prowadzone głównie na Dalekim Wschodzie, wschodniej Syberii, północnym szelfie kontynentalnym oraz Półwyspie Jamalskim. Ich celem nie będzie raczej zwiększenie wydobycia, ale uzyskanie nowych możliwości magazynowania i przerobu węglowodorów oraz budowa systemów kondensacji gazu ziemnego. Taki wniosek można wysnuć na podstawie wypowiedzi Aleksieja Tiekslera, pierwszego zastępcy ministra energetyki, który uważa, że w ciągu dekady obrót LNG prawdopodobnie osiągnie poziom porównywalny do sprzedaży gazu za pomocą tradycyjnych metod przesyłu (gazociągów) ${ }^{30}$. Inwestycje te powinny zostać skoncentrowane w regionach sachalińskim, irkuckim, Jakucji oraz Kraju Krasnojarskim, co wynika z przyjętych koncepcji eksportowych. Proces inwestycyjny obejmować będzie także modernizację wybranych rafinerii, infrastruktury przesyłowej koncernu Jednolite Systemy Energetyczne (UPS) ${ }^{31}$ oraz realizację

28 Za jeden z czynników umożliwiających zrównoważony rozwój społeczny uznano zapewnienie niezakłóconych dostaw energii na poziomie umożliwiającym indywidualnym odbiorcom wykorzystywanie ich w pełni. Projekt zakładał sztuczne utrzymanie ceny energii, która do $2035 \mathrm{r}$. dla detalicznego odbiorcy indywidualnego miała wynieść $0,09-0,10$ dol. za $1 \mathrm{kWh}$ wg kursu dolara amerykańskiego z 2010 r. Rozwiązanie to miało obniżyć koszt wydatków gospodarstw domowych na paliwa i energię elektryczną do poziomu $7 \%$ dochodów.

29 Prognoz naučno-tehnologičeskogo razwitiâ...

30 Važny tehnologičeskie kompetencii, „Kommersant"” [online], 15.05.2017 [dostęp: 21.11.2017], dostępny w internecie: <https://www.kommersant.ru/doc/3292668>.

31 Jest to zasadniczy element synchronicznej sieci przesyłowej WNP o mocy wytwórczej 300 GW, obsługujący 280 mln odbiorców. Rosyjską część stanowi sześć zintegrowanych regionalnych systemów przesyłowych. 
przedsięwzięć umożliwiających wykorzystanie szerszej gamy lokalnych nośników energii (zwłaszcza zasobów wodnych na Syberii i Dalekim Wschodzie oraz energii słonecznej) $)^{32}$. W drugim etapie zasadniczymi inwestycjami będą:

- przedsięwzięcia pozwalające na przesył gazu przez dwie nitki rurociągu Siła Syberii ${ }^{33}$,

- projekty umożliwiające pełne wykorzystanie Amurskiego Zakładu Przetwórstwa Gazu w Biełogorsku,

- rozbudowa infrastruktury do eksportu LNG na Półwyspie Jamalskim i Sachalinie ${ }^{34}$,

- realizacja inwestycji w Amurskich Zakładach Przetwórstwa Gazu ${ }^{35}$.

Kolejnym celem średniookresowym jest uzyskanie możliwości eksportu oleju opałowego oraz energii elektrycznej do państw WNP i Azji kontynentalnej. Zależy to jednak od czynników stricte politycznych. Przede wszystkim Rosja musi uznać Chiny nie tylko za importera, ale także państwo tranzytowe, co powoduje, że budowa sieci odbiorców musi uwzględnić także interesy strategiczne Pekinu. Warunkiem uzyskania możliwości eksportu energii oraz nieprzetworzonych surowców energetycznych jest także utrzymanie dotychczasowych form współpracy z Turcją i Kazachstanem. Celem polityki Moskwy wobec Ankary jest uzyskanie jej akceptacji dla rosyjskiej aktywności na obszarze śródziemnomorsko-czarnomorskim, zwłaszcza formuły energetycznego wiązania tego regionu ${ }^{36}$. Osiąga go poprzez angażowanie się w rozbudowę tureckiego przemysłu energetycznego - eksport technologii oraz współpracę w zakresie budowy elektrowni jądrowych. Kazachstan natomiast postrzegany jest jako państwo, które współkreuje wraz z Rosją kooperację energetyczną krajów WNP. Jego pozycja wynika z przekonania rosyjskich strategów i polityków, że bez udziału Astany niemożliwe jest funkcjonowanie Euroazjatyckiej Przestrzeni Gospodarczej, a co za tym idzie - wspólnej przestrzeni energetycznej. Dodatkowym czynnikiem wpływającym na status

32 W latach 2015-2017 na terenie Rosji uruchomiono 19 elektrowni słonecznych o łącznej mocy $210 \mathrm{MW}$.

33 Budowa ma zostać zakończona do 20.12.2019 r. Kontrakt zakłada dostawę do Chin $38 \mathrm{mld} \mathrm{m}^{3}$ gazu rocznie.

34 Obecnie największymi odbiorcami gazu skroplonego są Japonia i Korea Południowa. Większe możliwości eksportowe mają zapewnić terminale gazowe Jamał LNG, Władywostok LNG i Sachalin LNG.

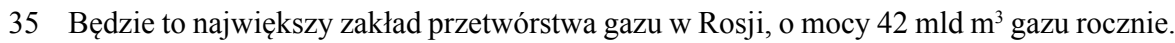
Docelowo będzie także produkował rocznie $60 \mathrm{mln} \mathrm{m}^{3}$ helu.

36 Rosja osiąga ten cel poprzez budowę na terytoriach tamtejszych państw infrastruktury magazynowo-przesyłowej. 
Kazachstanu jest stanowisko Chin wobec poziomu importu gazu z Rosji i Azji Centralnej oraz współzależności pomiędzy obydwoma kierunkami sprowadzania tego surowca.

Wynikająca $\mathrm{z}$ tych uwarunkowań formuła kooperacji w ramach przestrzeni energetycznej WNP nadal obejmować będzie takie obszary, jak wydobycie i eksport ropy naftowej, gazu ziemnego i węgla oraz obrót produktami naftowymi i energią elektryczną. Dla Rosji priorytetem będzie tu obrót produktami przetworzonymi i energią elektryczną, w zamian za co pozostałe państwa WNP będą mogły zwiększyć swój udział w eksporcie surowców energetycznych. Warunkiem, który determinuje to rozwiązanie, jest ich przesył istniejącymi systemami transportowymi. Pozwoli to Rosji kontrolować skalę eksportu oraz poszerzać integrację gospodarczą państw WNP.

Przyjęte założenia odnośnie do modernizacji sektora paliwowo-energetycznego określą także sposób oddziaływania międzynarodowego oraz zakres przeobrażeń rosyjskiej polityki bezpieczeństwa. Zarówno polityka zagraniczna, jak i bezpieczeństwa podporządkowane zostaną zasadniczemu celowi strategicznemu, jakim jest uzyskanie statusu globalnego eksportera nośników energii. Aktywność na tym polu koncentrować się będzie na próbach ograniczania amerykańskiej hegemonii w zakresie kontroli szlaków transportowych. Na akwenach południowego Pacyfiku, Morzu Śródziemnym i - w mniejszym stopniu - na Bałtyku działania te będą prowadzone w kooperacji z Chinami ${ }^{37}$, samodzielne natomiast - $\mathrm{w}$ regionach arktycznym (zwłaszcza na akwenie Oceanu Arktycznego) oraz kaspijsko-czarnomorskim. Możliwa jest odbudowa trójkąta strategicznego Rosja-Chiny-Iran ${ }^{38}$, zwłaszcza po podpisaniu konwencji o statusie Morza Kaspijskiego, Teheran jest bowiem potencjalnie istotnym sojusznikiem Moskwy w kreowaniu sytuacji politycznej w regionie kaspijskim (może stanowić dla niej wsparcie m.in. w polityce ograniczania możliwości współpracy pozostałych sygnatariuszy tego porozumienia). Samodzielne przedsięwzięcia Rosji mające na celu kształtowanie ładu międzynarodowego prowadzone będą z wykorzystaniem potencjału militarnego, zwłaszcza floty wojennej i sił specjalnych. Świadczą o tym zarówno przebudowa sił zbrojnych, jak i cele strategiczne na zasadniczych kierunkach narodowej polityki morskiej. Zmiany w strukturze organizacyjnej, dyslokacja

37 Szerzej: P. Mickiewicz, Rosyjsko-chińska aktywność..., s. 85-99.

38 Tenże, Trójkąt Rosja-Chiny-Iran i jego miejsce na arenie międzynarodowej, [w:] Mocarstwowość na przełomie XX $i$ XXI wieku. Teorie - analizy - prognozy, red. S. Wojciechowski, M. Tomczak, Wydawnictwo Naukowe Wyższej Szkoły Nauk Humanistycznych i Dziennikarstwa, Poznań 2010, s. 147-168. 
oddziałów (zwłaszcza sił specjalnych) oraz plany modernizacji potencjału floty wojennej jednoznacznie wskazują, że siły te mają być przygotowane zarówno do działań defensywnych (blokowania dostępu do Morza Czarnego i Oceanu Arktycznego), jak i ofensywnych. Powinny być one zdolne do pełnego kontrolowania kluczowych dla Rosji szlaków żeglugowych, a także niwelowania możliwości operowania na nich sił morskich innych graczy i prowadzenia działań stricte sabotażowo-dywersyjnych. Należy jednak podkreślić, że działania ofensywne będą raczej przybierały formę wywoływania u potencjalnego przeciwnika poczucia zagrożenia i czasowego blokowania możliwości prowadzenia przez niego żeglugi niż operacji militarnych skierowanych przeciwko państwom uznanym za przeciwników ${ }^{39}$.

\section{Podsumowanie}

Rosyjska polityka energetyczna znajduje się obecnie w okresie transformacji, której istotą jest dostosowanie sektora paliwowo-energetycznego do przewidywanych przeobrażeń na globalnym rynku energetycznym. Ocen koncepcji reformy tego sektora rosyjskiej gospodarki nie można jednak ograniczać do działań ukierunkowanych na zwiększenie efektywności, ponieważ odgrywa on decydującą rolę w budowie potencjału państwa i współtworzy zasadnicze instrumenty oddziaływania międzynarodowego. Jego modernizacja traktowana jest więc jako element polityki sankcjonowania globalnej pozycji państwa i z tego względu została ściśle powiązana z polityką eksportową oraz działaniami ukierunkowanymi na polityczno-gospodarcze wiązanie wybranych regionów globu. Obecne założenia rozwojowe odnoszą się głównie do zagrożeń, jakie stanowią dla Rosji nowa amerykańska polityka eksportu nośników energii, zmiany w unijnej strategii energetycznej oraz wzrost znaczenia przetworzonych surowców energetycznych w globalnym bilansie energetycznym i obrocie międzynarodowym. Nie oznacza to, że ocena tych zagrożeń przyczyniła się do radykalnej zmiany rosyjskich celów strategicznych. Przeformatowaniu uległa tylko formuła prowadzonych działań, które koncentrują się obecnie na przeciwdziałaniu amerykańskiej polityce eksportowej oraz dostosowaniu własnego eksportu do specyfiki zapotrzebowania globalnego rynku energetycznego. Uwarunkowania te wymusiły zmianę sposobu

39 Powinny one przybrać formę incydentów polityczno-militarnych, prowadzonych zarówno w sposób oficjalny, jak i skryty. Będą one zbliżone do działań podejmowanych od roku 2013 wobec Wielkiej Brytanii, Szwecji oraz przebywających na Morzu Bałtyckim sił morskich Stanów Zjednoczonych. Zob. P. Mickiewicz, Battycka ,,zimna wojna”... 
funkcjonowania rosyjskiego sektora paliwowo-energetycznego oraz polityki energetycznej na rynku wewnętrznym. Potencjalny spadek dochodów z eksportu surowców oraz skala niezbędnych inwestycji w przemysł paliwowo-energetyczny mogą zagrozić stabilności finansowej państwa, a na pewno zakłócić realizację zaplanowanych procesów modernizacyjnych i rozwojowych. Koncepcja przeciwdziałania tym zagrożeniom zakłada prowadzenie skoordynowanych działań na arenie międzynarodowej oraz modernizację poszczególnych sfer rosyjskiej gospodarki. Oddziaływanie na zewnętrz to tworzenie nowych rynków zbytu poprzez wykorzystanie obrotu przetworzonymi nośnikami energii oraz zdecydowana reakcja na wszelkie formy przeciwdziałania rosyjskiej ekspansji eksportowej ze strony innych graczy, zwłaszcza USA. Zasadniczymi instrumentami niwelowania zagrożeń dla bezpieczeństwa ekonomicznego na rynku wewnętrznym są modernizacja sektora paliwowo-energetycznego oraz zwiększenie efektywności energetycznej rosyjskiego przemysłu i odbiorców indywidualnych.

Realizacja całokształtu projektowanej polityki energetycznej będzie procesem kosztochłonnym i wymagającym zaawansowanych technologii. Założone cele strategiczne można osiągnąć, ale zależy to od kilku czynników. Pierwszoplanowy jest tu stosunek Chin do azjatyckiego kierunku rosyjskiej ekspansji ekonomicznej. Jako istotny importer rosyjskich nośników energii i współinwestor części projektów energetycznych i przesyłowych mogą one skutecznie ograniczyć ich rentowność, a w niektórych przypadkach także możliwość realizacji. Drugą determinantą jest skala i czas trwania embarga nałożonego na Rosję przez Unię Europejską. Przekłada się ono wprost na ograniczenie możliwości importowania niezbędnego sprzętu oraz wykorzystania europejskiej myśli technologicznej i zasobów finansowych. Trzecim czynnikiem jest ograniczony wpływ Rosji na ceny surowców energetycznych (w przypadku gazu potęguje to amerykańska polityka eksportowa). Jedną z potencjalnych form rosyjskiej reakcji może być próba siłowego ograniczenia pozycji innych graczy na globalnym rynku energii, wymuszenia na państwach importerach prowadzenia polityki importowej zgodnie z oczekiwaniami Rosji, a nawet działania ukierunkowane na przerwanie ciągłości dostaw.

Reasumując, tworzona obecnie długofalowa strategia energetyczna jawi się jako przemyślana, oparta na realnych przesłankach koncepcja zmierzenia się z negatywnymi trendami, które oddziałują na ten sektor rosyjskiej gospodarki i politykę Federacji Rosyjskiej. Jest jednak tylko koncepcją, której powodzenie warunkuje szereg determinant, a na część z nich państwo rosyjskie nie ma realnego wpływu. Kierując się interesem narodowym, Moskwa 
może jednak podejmować działania polityczno-ekonomiczne i militarne, których celem będzie ograniczenie skali negatywnych procesów oddziałujących na państwo oraz wymuszenie uwzględnienia rosyjskich interesów przez importerów lub kraje tranzytowe.

\section{Bibliografia}

Doklad o realizacii transportnoj strategii Rossijskoj Federacii na period do 2030 goda. Otčetnyj period: 2015 god, Ministerstvo transporta Rossijskoj Federacii, Moskva 2016, dostępny w internecie [dostęp: 21.04.2017]: <https://www.mintrans.ru/file/401707>.

Effect of increased levels of liquefied natural gas exports on U.S. energy markets, U.S. Energy Information Administration, Washington, October 2014, dostępny w internecie [dostęp: 16.03.2018]: <https://www.eia.gov/analysis/requests/fe/pdf/lng.pdf>.

Ènergetičeskâ̂ strategiâ Rossii na period do 2035 goda [projekt], dostępny w internecie [dostęp: 10.09.2017]: <https://minenergo.gov.ru/system/download-pdf/1920/69055>.

Koncepciâ vně̌nej politiki Rossijskoj Federacii (utverždena Prezidentom Rossijskoj Federacii V.V. Putinym 30 noâbrâ 2016 g.), „Ministerstvo inostrannyh del Rossijskoj Federacii” [online, dostęp: 12.10.2017], dostępny w internecie: $<$ http://www.mid.ru/foreign_policy/ news/-/asset_publisher/cKNonkJE02Bw/content/id/2542248>.

Koncepcja polityki zagranicznej Federacji Rosyjskiej (zatwierdzona przez Prezydenta Federacji Rosyjskiej Vladimira Putina 30 listopada 2016 r.), „Ambasada Rosji w Polsce" [online, dostęp: 21.04.2017], dostępna w internecie: <http://poland.mid.ru/ web/polska_pl/koncepcja-polityki-zagranicznej-federacji-rosyjskiej/-/asset_publisher/ x9WG6FhjehkG/content/koncepcja-polityki-zagranicznej-federacji-rosyjskiej-zatwierdzona-przez-prezydenta-federacji-rosyjskiej-vladimira-putina-30-listopada-2016-r-? inheritRedirect $=$ false $\&$ redirect $=\mathrm{http} \% 3 \mathrm{~A} \% 2 \mathrm{~F} \% 2 \mathrm{Fpoland}$.mid.ru $\% 2 \mathrm{Fweb} \% 2 \mathrm{Fpol}-$ ska_pl\%2Fkoncepcja-polityki-zagranicznej-federacji-rosyjskiej\%3Fp_p_id\%3D101_ INSTANCE_x9WG6FhjehkG\%26p_p_lifecycle \% 3D0\%26p_p_state $\% 3$ Dnormal $\% 26 p$ p_mode\%3Dview\%26p_p_col_id\%3Dcolumn-2\%26p_p_col_count\%3D1>.

Kosowska K., Kosowski P., Perspektywy rozwoju LNG w Rosji, „Zeszyty Naukowe Instytutu Gospodarki Surowcami Mineralnymi i Energią PAN" 2016, nr 95.

Mickiewicz P., Battycka ,zimna wojna”. Możliwe reakcje NATO i UE na rosyjska aktywność militarna na akwenie battyckim, „Krakowskie Studia Międzynarodowe” 2015, nr 2 (12).

Mickiewicz P., Ewolucja rosyjskiej polityki bezpieczeństwa i doktryny obronnej $w$ drugiej dekadzie XXI wieku, [w:] Rosyjska myśl strategiczna i potencjat militarny w XXI wieku, red. P. Mickiewicz, Wydawnictwo Naukowe PWN, Warszawa 2018.

Mickiewicz P., Obszar czarnomorski i Morze Śródziemne w polityce Rosji, „Rocznik Bezpieczeństwa Międzynarodowego" 2016, vol. 10, nr 1.

Mickiewicz P., Polityka bezpieczeństwa i doktryna obronna FR na przełomie XX i XXI wieku, [w:] Rosyjska myśl strategiczna i potencjat militarny w XXI wieku, red. P. Mickiewicz, Wydawnictwo Naukowe PWN, Warszawa 2018.

Mickiewicz P., Rosyjsko-chińska aktywność morska i koncepcje obecności na akwenie baltyckim. Pomiędzy rywalizacja a wspótpraca, „Krakowskie Studia Międzynarodowe” 2018, nr 3 (15). 
Mickiewicz P., Trójkąt Rosja-Chiny-Iran $i$ jego miejsce na arenie międzynarodowej, [w:] Mocarstwowość na przełomie XX i XXI wieku. Teorie - analizy - prognozy, red. S. Wojciechowski, M. Tomczak, Wydawnictwo Naukowe Wyższej Szkoły Nauk Humanistycznych i Dziennikarstwa, Poznań 2010.

Mocarstwowość na przełomie XX i XXI wieku. Teorie - analizy - prognozy, red. S. Wojciechowski, M. Tomczak, Wydawnictwo Naukowe Wyższej Szkoły Nauk Humanistycznych i Dziennikarstwa, Poznań 2010.

Morskâ doktrina Rossijskoj Federacii, dostępna w internecie [dostęp: 21.04.2017]: <http:// static.kremlin.ru/media/events/files/ru/uAFi5nvux2twaqjftS5yrIZUVTJan77L.pdf>.

Prognoz naučno-tehnologičeskogo razvitiâ otraslej toplivno-ènergetičeskogo kompleksa Rossii na period do 2035 goda, Ministerstvo ènergetiki Rossijskoj Federacii, Moskva 2016, dostępny w internecie: <https://minenergo.gov.ru/view-pdf/6365/66647>.

Rosyjska myśl strategiczna i potencjał militarny w XXI wieku, red. P. Mickiewicz, Wydawnictwo Naukowe PWN, Warszawa 2018.

Strategiâ razvitiâ vnutrennego vodnogo transporta Rossijskoj Federacii na period do 2030 goda, „Pravitel'stvo Rossii” [online, dostęp: 21.04.2017], dostępna w internecie: <http:// static.government.ru/media/files/YxvWxYkzMqwAsfBmAX6anAVViKnFgYwA.pdf>.

Ukaz Prezidenta Rossijskoj Federacii „O Strategii èkonomičeskoj bezopasnosti Rossijskoj Federacii na period do 2030 goda”, ,Èlektronnyj fond pravovoj i normativno-tehničeskoj dokumentacii” [online], 15.05.2017 [dostęp: 12.09.2017], dostępny w internecie: <http:// docs.cntd.ru/document/420398070>.

Ukaz Prezidenta Rossijskoj Federacii ot 31 dekabrâ 2015 goda N 683 „O Strategii nacional'noj bezopasnosti Rossijskoj Federacii”, „Rossijskaâ gazeta” [online], 31.10.2015 [dostęp: 21.04.2017], dostępny w internecie: $<$ https://rg.ru/2015/12/31/nac-bezopasnost-site-dok.html > . Važny tehnologičeskie kompetencii, „Kommersant"”' [online], 15.05.2017 [dostęp: 21.11.2017], dostępny w internecie: <https://www.kommersant.ru/doc/3292668>.

Voytyuk O., Sektor naftowy Ukrainy. Historia i przyszłość, „Polityka Energetyczna” 2015, t. 18, z. 2. 